\title{
Aktualisasi Pengelolaan Dana Lingkungan Hidup di Indonesia: Mencegah Penyimpangan Prinsip Pencemar Membayar dan Earmarking
}

\author{
Adryan Adisaputra Tando ${ }^{1}$ dan Theresia E.K. Hindriadita ${ }^{2}$
}

\begin{abstract}
Abstrak
Tahun 2018 adalah momentum kebangkitan pemerintah berorientasi lingkungan hidup. Hal demikian bukan hanya karena penegakan hukum lingkungan yang semakin masif dilakukan, akan tetapi juga karena adanya perkembangan kebijakan yang bernuansa hijau. Pada September 2018, Pemerintah menerbitkan Peraturan Presiden Nomor 77 Tahun 2018 tentang Pengelolaan Dana Lingkungan Hidup. Langkah ini merupakan salah satu bentuk implementasi Nawacita ketujuh. Tetapi, ada beberapa hal yang perlu dikaji ulang terkait dengan sumber dan alokasi pendanaan lingkungan. Singkatnya, detail pengaturan kedua hal tersebut berpotensi menyimpangi prinsip pencemar membayar. Peraturan ini menjadikan APBN dan APBD sebagai sumber dana lingkungan serta melakukan penggabungan alokasi dana yang berasal dari dua jenis dana berbeda. Dampaknya, peraturan yang awalnya menjadi harapan bagi lingkungan hidup berpotensi menjadi bumerang bagi masyarakat, pemerintah, dan lingkungan hidup itu sendiri. Tulisan ini merupakan suatu bentuk analisis kritis Peraturan Presiden Nomor 7 Tahun 2018 agar mampu membawa dampak baik untuk pemerintahan selanjutnya.
\end{abstract}

Kata Kunci: Dana Lingkungan Hidup, Sumber Pendanaan, Alokasi Pendanaan, Prinsip Pencemar Membayar

\begin{abstract}
The year 2018 is the year of environmental-oriented government. This is not only because of the massive enforcement toward environmental damage, but also the increasing number of green policies. On September 2018, the government published a President Regulation Number 77 of 2018 on the Management of Environmental Funds. This action is one of the implementations of the seventh Nawacita. However, there are several issues need to be reviewed and criticized related to the source and earmarking of environmental funds. Shortly, the regulation of those two could violate the polluter pays principle. This regulation uses APBN and APBD as its sources of fund and merges the allocation of two different sources of fund. As a result, it would be a boomerang for people, government, and the environment itself. This paper aims to critic the President Regulation Number 7 of 2018 in order to give feedback for improving the next government. Keywords: Environmental Funds, Source of Funding, Allocation of Funding, Polluter Pays Principle

\footnotetext{
${ }^{1}$ Penulis merupakan Mahasiswa Fakultas Hukum Universitas Indonesia.

2 Penulis memperoleh gelar Sarjana Hukum dari Fakultas Hukum Universitas Indonesia pada tahun 2018.
} 


\section{Pendahuluan}

Pada akhir tahun 2018, Pemerintah menerbitkan Peraturan Presiden Republik Indonesia Nomor 77 tahun 2018 tentang Pengelolaan Dana Lingkungan Hidup (selanjutnya disebut Perpres 77/2018). Peraturan ini merupakan peraturan lanjutan dari Pasal 30 ayat (3) Peraturan Pemerintah (PP) Nomor 46 Tahun 2017 (PP 46/2017) tentang Instrumen Ekonomi Lingkungan Hidup.

Pemerintahan Jokowi sendiri memberikan perhatian lebih terhadap pelestarian sumber daya alam dan lingkungan hidup. Hal tersebut dapat dilihat dalam Nawacita ketujuh pemerintahan Jokowi yang tercantum dalam Lampiran Peraturan Presiden Nomor 2 Tahun 2015 tentang Rencana Pembangunan Jangka Menengah Nasional (RPJMN) 2015-2019. Salah satu arah dan kebijakan Nawacita ketujuh adalah dengan melakukan penguatan instrumen pengelolaan lingkungan hidup serta sistem insentif dan disinsentif pengelolaan lingkungan hidup.

Perwujudan rencana tersebut dapat dilakukan dengan adanya pelaksanaan mobilisasi pendanaan melalui kerja sama kementerian/lembaga. ${ }^{3}$ Hal tersebut patut diapresiasi, namun di sisi lain, kebijakan ini dapat menjadi bumerang karena dalam pelaksanaan kebijakannya. Terdapat beberapa hal dalam norma pendanaan lingkungan di peraturan ini yang berpotensi menyebabkan implementasi yang tidak sesuai dengan prinsip pencemar membayar dan earmarking.

Dalam PP 46/2017, sebenarnya diatur 3 (tiga) jenis instrumen pendanaan lingkungan hidup, yaitu dana jaminan pemulihan lingkungan hidup, dana penanggulangan pencemaran dan/atau kerusakan dan pemulihan lingkungan hidup, serta dana amanah/bantuan untuk konservasi. Dari ketiga jenis tersebut, hanya dua jenis dana yang berkaitan dengan proses pemulihan dan penanggulangan pencemaran dan/atau kerusakan lingkungan hidup, yaitu dana jaminan pemulihan lingkungan hidup dan dana penanggulangan pencemaran dan/atau kerusakan dan pemulihan lingkungan hidup. Namun, dari dua jenis tersebut, yang telah menerapkan prinsip pencemar membayar hanya dana jaminan pemulihan lingkungan hidup ${ }^{4}$ saja.

Perbedaan utama dari dana jaminan pemulihan lingkungan hidup dengan dana penanggulangan pencemaran dan/atau kerusakan dan pemulihan lingkungan hidup adalah jenis dana

${ }^{3}$ Indonesia, Peraturan Presiden Tentang Rencana Pembangunan Jangka Menengah Nasional Tahun 20152019, Perpres No. 2 Tahun 2015, LN No. 3 Tahun 2015.

${ }^{4}$ Meskipun jenis dana ini setidaknya telah memenuhi prinsip pencemar membayar, sebenarnya terdapat beberapa kritik yang dapat diberikan terkait dengan pengaturannya. Akan tetapi, mengingat banyaknya hal yang perlu dibahas, maka kritik terhadap jenis dana ini nantinya akan dilakukan di dalam tulisan yang berbeda. 
kedua ini hanya dapat digunakan terhadap pencemaran yang tidak diketahui sumber atau pelakunya, sedangkan pencemaran yang sudah diketahui pencemarannya menggunakan dana jaminan pemulihan. Tetapi, meskipun dana penanggulangan pencemaran dan/atau kerusakan dan pemulihan lingkungan hidup hanya dapat digunakan terhadap wilayah yang tidak diketahui sumber atau pelaku pencemarannya, bukan berarti dana ini dapat menyimpangi prinsip pencemar membayar.

Tulisan ini fokus membahas potensi penyimpangan prinsip pencemar membayar dalam pengaturan tentang dana penanggulangan pencemaran dan/atau kerusakan lingkungan hidup. Selain itu, dana amanah bantuan/konservasi juga akan dibahas karena adanya potensi penyimpangan prinsip earmarking.

Perpres 77/2018 mengatur bahwa pengelolaan dana lingkungan hidup adalah suatu sistem dan mekanisme untuk mendanai upaya perlindungan lingkungan hidup dan pengelolaan lingkungan hidup. ${ }^{5}$ Pengelolaan dana ini terdiri dari 3 (tiga) bentuk kegiatan yaitu penghimpunan dana, pemupukan dana, dan penyaluran dana. ${ }^{6}$
Dalam kegiatan penghimpunan dana, ada 2 (dua) jenis dana yang perlu dihimpun, yaitu dana penanggulangan pencemaran dan/atau kerusakan lingkungan hidup dan pemulihan lingkungan hidup serta dana amanah/bantuan konservasi. ${ }^{7}$ Dana penanggulangan pencemaran dan/atau kerusakan dan pemulihan lingkungan hidup bersumber dari Anggaran Pendapatan dan Belanja Negara (APBN), Anggaran Pendapatan dan Belanja Daerah (APBD) dan sumber dana lainnya yang dapat berasal dari pajak dan retribusi lingkungan, ${ }^{8}$ sedangkan dana amanah/bantuan berasal dari hibah dan donasi. ${ }^{9}$ Untuk kegiatan penyaluran dana lingkungan hidup, harus dilakukan sesuai dengan kesepakatan dalam kontrak/perjanjian. ${ }^{10}$

Apabila dilihat secara kasat mata, Perpres 77/2018 seakan-akan tidak bermasalah dan menunjukan pemerintahan yang peduli terhadap lingkungan hidup. Hal ini dapat dilihat terutama dengan adanya peruntukan APBN dan APBD diarahkan kepada penanggulangan pencemaran dan/atau kerusakan dan pemulihan lingkungan. Tetapi apabila dianalisis, justru melalui kebijakan penggunaan APBN dan APBD ini timbul pertanya-

5 Indonesia, Peraturan Presiden Republik Indonesia tentang Pengelolaan Dana Lingkungan Hidup, Perpres No. 77 Tahun 2018, LN No. 160 Tahun 2018, Pasal 2 huruf d. Lihat juga dalam Pasal 1 angka 2 PP 46. 2017.

${ }^{6}$ Ibid.

${ }^{7}$ Ibid., Pasal 3 huruf a dan b.

${ }^{8}$ Ibid., Pasal 4 ayat 1 dan 2.

${ }_{9}$ Ibid., Pasal 4 ayat 3.

${ }^{10} \mathrm{Ibid}$., Pasal 6 ayat 1 . 
an, apakah hal ini telah sesuai dengan polluter pays principle (prinsip pencemar membayar)? Apakah penyaluran yang dilakukan telah sesuai dengan prinsip earmarking? Tulisan ini akan membahas kedua pertanyaan tersebut.

\section{Prinsip Pencemar Membayar: Suatu Kekhususan dalam Hu- kum Lingkungan}

Prinsip pencemar membayar diperkenalkan pertama kali oleh Organization for Economic Cooperation and Development (OECD) pada tahun 1972. Rekomendasi Guiding Principles Concering the International Economic Aspects of Environmental Policies menyebutkan bahwa prinsip pencemar membayar adalah: ${ }^{11}$

"The principle to be used for allocating costs of pollution prevention and control measures to encourage rational use of scarce environmental resources and to avoid distortions in international trade and investment is the so-called "Polluter-Pays Principle". This principle means that the polluter should bear the expenses of carrying out the above-mentioned measures decided by public authorities to ensure that the environment is in an acceptable state. In other words, the cost of the- se measures should be reflected in the cost of goods and services which cause pollution in production and/or consumption. Such measures should not be accompanied by subsidies that would create significant distortions in international trade and investment." (garis bawah oleh penulis)

Pada awal diperkenalkan, prinsip ini masih bersifat abstrak. Namun, rekomendasi OECD tersebut akhirnya membawa angin segar dalam perkembangan prinsip hukum lingkungan. Hal ini dapat dilihat dalam pengadopsian prinsip pencemar membayar dalam cerminan hukum lingkungan internasional baik yang berupa soft-law maupun yang bersifat hard-law.

Salah satu hukum internasional yang mengadopsi prinsip pencemar membayar adalah Deklarasi Rio tahun 1992. Prinsip ke 16 menyatakan adanya bentuk internalisasi dari biaya-biaya lingkungan dan instrumen ekonomi lainnya yang dibebankan kepada pencemar. ${ }^{12}$ Pada dasarnya prinsip pencemar membayar mewajibkan ongkos pencemaran ditanggungkan (should be borne) kepada mereka yang melakukan pencemaran. ${ }^{13}$ Bentuk tanggung jawab tersebut berupa

${ }^{11}$ OECD, Guiding Principles Concering the International Economic Aspects of Environmental Policies, Dalam OECD, The Polluter-Pays Principle: OECD Analyses and Recommendations (Paris, OECD, 1992), hlm 19.

${ }^{12}$ Sands dan Galizi meringkas Prinsip ke-16 Deklarasi Rio dengan menyatakan: menyatakan "Internalisation of environmental costs and economic instruments should be promoted in a manner that takes into account that the polluter should bear the cost of pollution." Philippe Sands, Paolo Galizi, Documents in International Environmental Law (Cambridge: Cambridge University Press, 2004), hlm. 18.

${ }^{13}$ Philippe Sands, Principles of International Environmental Law 2nd Edition (Cambridge: Cambridge University Press, 2003), hlm. 280 
ongkos untuk melakukan pencegahan dan kontrol terhadap pencemaran yang dicerminkan ke dalam harga-harga produksi atau jasa yang sifatnya mencemari lingkungan. ${ }^{14}$ Ongkos hasil cerminan itu nantinya harus ditujukan untuk menjaga lingkungan. Permasalahan yang perlu dijawab oleh prinsip pencemar membayar adalah siapa yang dimaksud pencemar, apa saja yang harus dibayar oleh pencemar, tujuan, dan bagaimana implementasinya dalam kebijakan lingkungan $?^{15}$

\section{A. Siapa yang dimaksud dengan Pencemar?}

Siapa itu Pencemar? Pertanyaan ini timbul seiring dengan adanya keharusan untuk membebankan tanggung jawab pemulihan kepada pihak yang melakukan pencemaran. Isu ini penting mengingat bahwa prinsip pencemar membayar bukan hanya mengenai etika saja akan tetapi juga keadilan dan pertanggungjawaban. ${ }^{16}$ Dalam hal pencemaran, sebenarnya setiap orang atau korporasi memiliki peran yang sama dalam suatu lingkaran produksi dan konsumsi yang berakibat pada pencemaran. ${ }^{17}$ Misalnya, terdapat kendaraan yang melakukan pencemaran udara. Siapakah pencemarnya? Pabrik yang melakukan produksi kendaraan tersebut atau pembeli kendaraan?

14 Alan Boyle dan Patricia Birnie, International Law and the Environment, 2nd Edition. (Oxford: Oxford University Press, 2002), hlm. 322.

${ }^{15} \mathrm{Hal}$ ini mengingat bahwa prinsip pencemar membayar ini juga memiliki unsur ekonomi yang kental untuk mewujudukan perlindungan lingkungan. (Laode M. Syarif, Maskun, dan Birkah Latif, Evolusi Kebijakan dan Prinsip-Prinsip Lingkungan Global dalam Laode M. Syarif dan Andri Wibisana, Hukum Lingkungan, Teori, Legislasi, dan Studi Kasus (Jakarta: INCLE, 2010, hlm. 55). Pendapat serupa juga diungkapkan oleh Van Lennep pada tahun 1970 yang menyatakan bahwa prinsip pencemar membayar difungsikan untuk mengontrol pencemar dengan biaya yang paling efektif (cost-effective) (Jan-Henrik Meyer, "Who Should Pay for Pollution? The OECD, the European Communities and the Emergence of Environmental Policy in the Early 1970s", European Review of History: Revue européenne d'histoire, 24:3, (2017), hlm. 4)

${ }^{16}$ Sharon Beder "The Polluter Pays Principle." dalam Sharon Beder, Environmental Principles and Policies. An Interdisciplinary Introduction, (London: Earthscan, 2006), hlm. 32.

${ }^{17}$ John Adler dan David Wilkinson, Environmental Law and Ethics (London: Macmillan Press, 1999), hlm. 177. 
Pada dasarnya pencemar adalah mereka yang baik secara langsung maupun tidak langsung menimbulkan kerugian (damages) kepada lingkungan atau mereka yang menciptakan kondisi untuk itu. ${ }^{18}$ Namun, umumnya para sarjana berpendapat bahwa alokasi biaya lingkungan yang ada pada pelaku usaha akan diteruskan kepada konsumen dalam wujud harga barang atau jasa. ${ }^{19}$ Dengan kata lain, yang dimaksud dengan pencemar adalah konsumen karena konsumen yang menanggung seluruh biaya lingkungan (environmental cost).

Akan tetapi, pada kenyataannya, penerapan mengenai siapa yang dimaksud dengan pencemar harus dilihat secara vis-à-vis dengan kondisi yang ada. The Comprehensive Environmental Response,
Compensation, and Liability Act (CERCLA) menyebutkan bahwa pencemar adalah:20

1. Pemilik atau operator fasilitas, terlepas apakah mereka yang memiliki atau mengoperasikan fasilitas pada saat pembuangan zat berbahaya (hazardous substance);

2. Pemilik atau operator masa lalu yang memiliki atau mengoperasikan saat terjadinya pembuangan zat berbahaya;

3. Setiap orang yang mengatur perawatan atau pembuangan zat berbahaya yang dimiliki oleh orang tersebut;

4. Setiap orang yang menerima atau diterima zat berbahaya untuk diangkut ke fasilitas pembuangan atau perawatan atau lokasi yang dipilih oleh orang yang darinya terlepas atau terancam dilepaskan.

\footnotetext{
${ }^{18}$ Joint Working Party on Trade and Environment, The Polluter-Pays Principle as It Relates to International Trade, (Paris: OECD, 2002), hlm. 11, Lengkapnya dinyatakan sebagai berikut: 'someone who directly or indirectly damages the environment or who creates conditions leading to such damage'.

${ }^{19}$ Dalam hal demikian alokasi yang diberikan kepada konsumen tersebut akan diwujdukan ke dalam permintaan pasar, harga yang dibayar oleh konsumen, ataupun pengurangan gaji atau keuntungan. Maka secara kasuistis Pearson menyatakan itu tidak ada bedanya dengan apa yang dinamakan Consumer Pays Principle. Lebih lanjut Selanjutnya sisa biaya polusi setelah memenuhi tujuan pengurangan polusi sebagaimana sudah ditetapkan oleh otoritas publik maka akan ditanggung oleh korban, dalam hal timbullah apa yang dinamakan dengan Victims Pays Principle. Dalam kesumpulannya, Pearson menyatakan hal demikian sejalan dengan apa yang dinyatakan oleh OECD dan European Commission ('EC'). Charles S. Pearson, "Testing the System: GATT + PPP=? "Cornell International Law Journal. Vol 27, Issue 3, Article 4 (1994), hlm. 555-556.

${ }^{20}$ Selengkapnya CERCLA menyatakan bahwa yang dimaksud dengan pencemar adalah mereka yang: 1) Current owners or operators of the facility, regardless of whether the owner or operator caused the release of the hazardous substance. 2)Past owners or operators, who owned or operated the facility at the time of disposal of the hazardous substance. 3) Any person who arranges for the treatment or disposal of the hazardous substance owned or possessed by that person. 4) Any person who accepts or accepted any hazardous substance for transport to disposal or treatment facilities, incinerators or sites selected by that person from which there is a release or a threatened release. Sebagaimana dikutip dari David Wilkinson, Law and Environment, (London: Roudledge Publishing, 2002) hlm. 125.
} 


\section{B. Apa Saja Biaya yang Harus Ditanggung oleh Pencemar?}

OECD pada tahun 1972 merekomendasikan bahwa pencemar bertanggung jawab atas ongkos pencegahan pencemaran dan langkah pengendalian (control measure).$^{21}$ Langkah pengendalian ini akan ditentukan oleh otoritas publik untuk menyatakan kelayakan lingkungan. Pencemar akan bertanggung jawab atas biaya untuk menjaga lingkungan. ${ }^{22}$ Biaya tersebut biasanya berupa biaya sistem kontrol terhadap pencemaran, pengeluaran lisensi (issuing licences), pengawasan atas emisi polusi dan lainnya. ${ }^{23}$
Melihat penjelasan tersebut, didapati bahwa isu kerusakan lingkungan kurang diperhatikan. ${ }^{24}$ Cordato menyatakan bahwa pencemar harus membayar dengan jumlah yang setara dengan kerusakan dan pembayaran ditujukan kepada orang yang dirugikan. Ia juga menyatakan bahwa benda mati dan lingkungan tidak mengalami kerugian namun orang pasti mengalami kerugian dan membutuhkan biaya ganti kerugian..$^{25}$ Sarana perwujudan dari kerugian lingkungan yang diakibatkan oleh orang lain dapat dilakukan melalui pertanggungjawaban perdata yang mana merupakan salah

${ }^{21}$ OECD, op.cit., hlm. 8.

22 Ibid., hlm. 13.

${ }^{23}$ Smets, H. 'The Polluter Pays Principle in the Early 1990s', dalam L. Campiglio, L. Pineschi, D. Siniscalco dan T. Treves (eds) The Environment After Rio: International Law and Economics, (London: Graham and Trotman, 1994). Lihat juga Pearson, op.cit., hlm. 556.

${ }^{24}$ Permasalahan environmental damage ini menjadi suatu masalah yang cukup pelik mengingat efek domino yang ditimbulkan. Lebih lanjut environmental damages juga memiliki sifat yang sulit untuk dikembalikan seperti semua (irreversible) dan juga secara luas/katastropik (catastrophic). Dalam hal ini Sunstein memberikan contoh beberapa hal di lingkungan misalnya rekayasa genetik, perubahan iklim, dan nuklir. Sekalipun dalam tulisannya Sunstein memberikan kritik terhadap asas pencegahan (precautionary principle) akan tetapi perlu dipahami bahwa Sunstein setuju bahwa environmental harm bersifat irreversible dan catastrophic. Cass R. Sunstein, "Irreversible and Catastrophic: Global Warming, Terrorism, and Other Problems: Eleventh Annual Lloyd K. Garrison Lecture on Environmental Law”, Pace Environmental Law Review, Vol. 23 (Januari, 2006).

Environmental damage apabila dibiarkan maka tidak hanya merugikan kepentingan generasi yang tinggal dan menikmati hasil dari lingkungan. Tetapi hal ini akan menjadi sebuah kerugian bagi generasi yang akan datang sebagaimana juga hal ini harusnya dilindungi. Padahal sebagai contoh bahwa apabila environmental damage dibiarkan maka akan merugikan generasi yang akan datang. Pada saat yang sama pula bahwa prinsip keadilan antar-generasi sudah menjadi prinsip-prinsip hukum lingkungan. Dalam hal ini Weiss memberikan empat kriteria keadilan anrar generasi yang harus dilindungi. Pertama yaitu perlindungan terhadap pilihan (conservation of options), perlindungan akan kualitas (conservation of quality), dan perlindungan atas akses (conservation of access). Edith Brown Weiss, "Our Rights and Obligations to Future Generations for the Environment", The American Journal of International Law, Vol. 84 (1990), hlm. 202.

${ }^{25}$ Roy E. Cordato, "The Polluter Pays Principle: A Proper Guide for Environmental Policy”, Institute for Research on the Economics of Taxation (IRET) Studies in Social Cost, Regulation and the Environment, No. 6, (2001), hal 1. Terkait pendapat Cordato, penulis setuju bahwa pencemar harus membayar dengan jumlah yang setara dengan pencemaran yang terjadi. Namun, penulis kurang setuju dengan pernyataan bahwa kerugian hanya perlu dibayarkan kepada orang yang dirugikan, tidak perlu terhadap 
satu perwujudan dari prinsip pencemar membayar. ${ }^{26}$

\section{Prinsip Pencemar Membayar: Tujuan Objektif dan Implemen- tasi}

Tujuan objektif dari prinsip pencemar membayar adalah internalisasi eksternalitas. ${ }^{27} \mathrm{Hal}$ ini dapat dilihat dalam Prinsip 16 Deklarasi Rio yang memberikan kesatuan diantara keduanya. ${ }^{28}$ Inter- nalisasi eksternalitas ini menjadi penting dikarenakan merupakan salah satu wujud terjadinya kegagalan pasar (market failure). ${ }^{29}$

Dalam konsep ekonomi, eksternalitas merujuk kepada suatu cara di mana produksi, transaksi pasar, atau perilaku konsumsi yang nantinya memengaruhi secara tidak langsung perilaku orangorang yang tidak terlibat dalam hal tersebut (third party). ${ }^{30}$ Akibat dari tidak

lingkungan. Seolah-olah pendapat ini menyatakan bahwa lingkungan yang rusak tidak perlu untuk dipulihkan. Padahal, lingkungan bukan benda mati. Lingkungan memiliki hak. Hal ini sejalan dengan pendapat dari Keraf yang berpegangan pada pendapat Taylor. Perkataan Taylor sebagaimana dikutip oleh Keraf, yang menyatakan, "Pertama, alam mempunyai hak untuk tidak diganggu gugat dan dirugikan. Alam mempunyai hak untuk tidak dirusak dan dicemari ... Kedua, manusia mempunyai kewajiban untuk membiarkan organisme berkembang sesuai dengan hakikatnya ... Singkatnya, "kita tidak boleh berusaha untuk memanipulasi, mengontrol, memodifikasi, atau "mengelola" ekosistem alamiah atau sebaliknya mengintervensi fungsi-fungsi alamiahnya." Lihat: A. Sonny Keraf, Etika Lingkungan Hidup, (Jakarta: Kompas, 2010), hal 141-142 dan Paul W. Taylor, Respect for Nature: A Theory of Environmental Ethics, (Princeton: Princeton University Press, 1986).

Berdasarkan hal tersebut kembali ditekankan sebagaimana halnya hak yang melekat pada subjek hukum lainnya, begitu pula dengan hak yang melekat pada lingkungan hidup pun tidak boleh dilanggar. Misalnya ketika terjadi pencemaran dan/atau perusakan lingkungan hidup, maka peristiwa itu dapat dikatakan dengan pelanggaran hak kepada lingkungan hidup. Secara otomatis maka para pencemar atau perusak itu dilekatkan tanggung jawab untuk memulihkan keadaan lingkungan hidup seperti keadaan semula. Lebih lanjut, Syarif dan Wibisana juga menyatakan bahwa lingkungan adalah Ibu Kehidupan, sehingga tanpa lingkungan, maka manusia tidak akan bisa bertahan hidup. Lingkungan adalah sumber hidup segala makhluk. Lihat: Laode M. Syarif dan Andri G. Wibisana, ed., op.cit.

${ }^{26}$ Andri Gunawan Wibisana, Prinsip-Prinsip Hukum Lingkungan, Bahan Ajar Fakultas Hukum Universitas Indonesia, Minggu II, Draft Oktober 2014, hlm. 57.

${ }^{27}$ OECD, op.cit., hlm. 14.

${ }^{28}$ Andri Gunawan Wibisana, op.cit., hlm. 57.

${ }^{29}$ Menurut Cooter dan Ulen ada empat alasan terjadi kegagalan pasar. Pertama adalah posisi yang tidak seimbang masing-masing aktor pasar. Dalam hal ini dapat dikatakan sebagai sebuah kondisi, hal tersebut tentu saja tidak ideal dikarenakan seharusnya dalam pasar setiap pelaku dalam posisi sama kuat dalam pengambilan keputusan. Dengan kata lain, konsumen tidak memiliki kekuatan untuk menentukan pilihan dan harus mengikuti apa yang dinyatakan oleh produsen. Kedua, adanya informasi yang tidak seimbang atau asymmetry information. Pelaku usaha akan mengambil keuntungannya sebanyak mungkin dari ketidaktahuan konsumen. Ketiga, kegagalan pasar tercermin dari adanya barang publik. Dimana setiap individu merasa tidak ada kewajiban untuk mengadakannya akan tetapi terus menggunakannya. Contoh klasik dari barang publik ini adalah sinar mercusuar, dimana setiap individu merasa akan mendapatkan manfaatnya tanpa bisa dikurangi. melihat hal demikian masing-masing individu yang sadar dan rasional tentu tidak akan mau memasang mercusuar tersebut sehingga tidak ada satupun pihak yang memasang sinar di mercusuar. Terakhir, adalah eksternalitas yang tidak pernah diinternalisasi oleh pelaku usaha. Robert Cooter dan Thomas Ulen, Law and Economics, 6th edition, (New York: Addison-Wesley, 2012), hlm. 38-41.

${ }^{30}$ R. C. d' Arge dan E. K. "Hunt, Environmental Pollution, Externalities, and Conventional Economic Wisdom: A Critique", B.C. Environmental Affair Law Review. Vol. 1 (1971), hlm. 266. 
dihitungnya biaya ke dalam manfaat tersebut akan berdampak pada masyarakat sebagai pihak yang menanggung segala biaya yang ada. ${ }^{31}$ Eksternalitas dapat timbul juga karena manusia yang selalu berusaha mencari keuntungan maksimum tanpa memikirkan pihak lain (self interested), ${ }^{32}$ sehingga dalam hal ini pasar telah gagal ${ }^{33}$ mencerminkan harga sebenarnya. Jadi dapat dikatakan bahwa eksternalitas berbentuk perbedaan harga antara private costs dengan social cost. ${ }^{34}$ Eksterna- litas ini merupakan sebuah contoh klasik dari bagaimana ketidakmampuan pasar dalam menjaga aset lingkungan (environmental asset). ${ }^{35}$

Dalam konteks lingkungan hidup, salah satu wujud pengambilan kebijakan internalisasi eksternalitas adalah dengan penerapan pajak lingkungan. ${ }^{36} \mathrm{Hal}$ ini juga didukung oleh mayoritas ekonom yang menyatakan bahwa bentuk optimal regulasi kepada pelaku usaha yang melakukan eksternalitas negatif adalah

${ }^{31}$ Draper meuyatakan bahwa eksternalitas merupakan salah satu dari tiga hal yang mempengaruhi analisis biaya-keuntungan/cost and benefit analysis ('CBA'). Dua hal lainnya yang mempengaruhi CBA adalah isu hak kepemilikan properti (property rights) dan permasalahan implisit dari pemasukan CBA dalam peraturan pemerintah. John William Draper, "Why Law Now Needs to Control Rather than Follow Neo-Classical Economics", Pace Environmental. Law Review, Vol. 33 (2016), hlm. 194.

${ }^{32}$ Hal ini juga dapat dipahami dalam pandangan model Neo Klasik. Menurut Mixon, ada dua perilaku utama manusia dalam hal Neo Klasik. Pertama, manusia adalah pihak yang rasional. Kedua manusia selalu memikirkan diri sendiri (selfinterested). Nixon pun menambahkan bahwa di dalam suatu pasat tidak akan orang-orang yang jujur, dapat dipercaya (truthful) adil (fair), dan sebagainya kecuali mereka mendapatkan keuntungan dari perilaku yang dilakukan tersebut. John Mixon, "Neoclassical Economics and the Erosion of Middle-Class Values: An Explanation for Economic Collapse", Notre Dame Journal Law Ethics \& Public Policy, Vol. 24 (2010), hlm. 327-328.

${ }^{33}$ Menurut Cooter dan Ulen ada empat alasan terjadi kegagalan pasar. Pertama adalah posisi yang tidak seimbang masing-masing aktor pasar. Dalam hal ini dapat dikatakan sebagai sebuah kondisi, hal tersebut tentu saja tidak ideal dikarenakan seharusnya dalam pasar setiap pelaku dalam posisi sama kuat dalam pengambilan keputusan. Dengan kata lain, konsumen tidak memiliki kekuatan untuk menentukan pilihan dan harus mengikuti apa yang dinyatakan oleh produsen. Kedua, adanya informasi yang tidak seimbang atau asymmetry information. Pelaku usaha akan mengambil keuntungannya sebanyak mungkin dari ketidaktahuan konsumen. Ketiga, kegagalan pasar tercermin dari adanya barang publik. Dimana setiap individu merasa tidak ada kewajiban untuk mengadakannya akan tetapi terus menggunakannya. Contoh klasik dari barang publik ini adalah sinar mercusuar, dimana setiap individu merasa akan mendapatkan manfaatnya tanpa bisa dikurangi. melihat hal demikian masing-masing individu yang sadar dan rasional tentu tidak akan mau memasang mercusuar tersebut sehingga tidak ada satupun pihak yang memasang sinar di mercusuar. Terakhir, adalah eksternalitas yang tidak pernah diinternalisasi oleh pelaku usaha. Robert Cooter dan Thomas Ulen, Law and Economics, 6th edition, (New York: Addison-Wesley, 2012), hlm. 38-41.

${ }^{34}$ Robert S. Pindyck dan Daniel L. Rubinfeld, Microeconomics, (Prentice Hall, 2001), hlm. 592.

${ }^{35}$ Arrow, K. "The Organization of Economic Activity: Issues Pertinent to the Choice of Market Versus Nonmarket Allocation", (Disampaikan pada The Analysis and Evaluation of Public Expenditures: The PPB System), Washington D.C: Joint Economic Committee, 91st Congress, 47-64, 1969. Lihat juga: E. Mansfield, Principles of Microeconomics (New York: W.W. Norton \& Company, 1983), hal. 73-76. Lihat juga dalam John Mixon, op.cit., hlm. 328.

${ }^{36}$ William J. Baumol dan Wallace E. Oates, The Theory of Environmental Policy (Cambridge: Cambridge University Press, 1988), hlm. 22. 
pajak. ${ }^{37}$

Ide tersebut diawali dari pemikiran awal seorang ekonom Inggris, Arthur Cecil Pigou. Dalam pandangannya, ia fokus kepada maksimalisasi kesejahteraan (welfare maximixation) dan membangun teori efisiensi ekonomi untuk pendapatan nasional (national dividend) serta membawa dampak kepada tingkat optimalisasi jika eksternalitas biaya lingkungan dapat diinternalisasi. ${ }^{38}$ Teori yang dibawa oleh Pigou tersebut dikenal secara umum dengan sebutan Pigouvian Tax.

Latar belakang pemikiran Pigou diawali dengan melihat adanya kewajiban untukalokasi yang tepat antara biaya oleh pelaku usaha, baik pencemar maupun tercemar, akan menemukan titik yang seimbang dengan cara membandingkan manfaat sosial dan biaya sosial dari kegiatan tersebut. ${ }^{39}$ Pajak lingkungan ini nanti akan memberikan suatu tekanan untuk mencari titik seimbang (equivalency) antara private costs dengan social costs yang timbul dari produksi atau aktivitas. ${ }^{40}$ Misalnya, suatu pabrik A (sebelum dikenakan pajak lingkungan) memiliki keuntungan sebesar 5, namun A menyebabkan kerugian lingkungan sebesar 10 . Maka dari itu, kerugian sebesar 10 nantinya akan diinternalisasi melalui pajak sebesar 10 pula dan harus ditanggung oleh A. Jika skema tersebut diterapkan, kemungkinan besar A tidak akan mau mencemari karena nilai keuntungannya akan lebih kecil dibandingkan kerugian yang ditanggung.

Awalnya tujuan dari pajak lingkungan adalah memperoleh keuntungan ganda (double dividend), yaitu keuntungan bagi lingkungan dan keuntungan ekonomi. ${ }^{41}$ Pengenaan pajak lingkungan akan menciptakan keuntungan bagi lingkungan yang pada akhirnya akan menghasilkan efisiensi ekonomi. ${ }^{42}$

Namun demikian, keuntungan ganda menimbulkan permasalahan lain apabila tidak dilakukan earmarking, ka-

${ }^{37}$ Agnar Sandmo, “Direct Versus Indirect Pigouvian Taxation," European Economic Review, Vol. 7 (1976). Dalam tulisannya Sandmo menjelaskan secara rinci bagaimana cara kerja pajak dalam melakukan internaliasi eksternalitas untuk mencapai titik optimum.

${ }^{38}$ Arthur Cecil Pigou, The Economics of Welfare, (London: Macmillian and Co., Limited, 2002), hlm. 192.

${ }^{39}$ Claudia Alexandra Dias Soares, "The Design Features of Environmental Tax", Doctoral Thesis, London School of Economics, September 2011, hlm. 36.

${ }^{40}$ Kondisi tersebut baru akan terpenuhi ketika ongkos marginal yang tidak dikompensasi dapat diinternalisasi lewat pajak kepada suatu organ (agents) yang menyebabkan terjadinya eksternalitas. Logika simetris tersebut harus diimplementasikan pada kasus terjadinya biaya eksternal (external cost) dimana manfaat eksternal (external benefits) terjadi sebaliknya. Dalam hal demikian, pajak harus disubtitusi dengan subsidi kepada organ-organ ekonomi yang berkepentingan. Ibid.

${ }^{41}$ Michael Faure, Marjan Peeters, dan Andri G. Wibisana, "Economic Instruments: Suiteed Developing Countries?", dalam Michael Faure dan Nicole Niessen, Environmental Law in Development: Lesson from the Indonesian Experience (Northampton, Edward Elgar, 2010), hlm. 231.

${ }^{42}$ Misalnya Terkla memberikan contoh bahwa effluent charges dapat meningkatkan efisiensi ekonomi dengan memberikan pungutan (charges) kepada pencemar untuk biaya kesmpatan yang sebenarnya 
rena pajak lingkungan yang seharusnya ditujukan untuk lingkungan berpotensi digunakan untuk hal lain. Andersen menyatakan, "modern externality theory hardly deals with the question of what should happen to the revenues from externality taxes". ${ }^{4}$ Hal ini akan membawa permasalahan kepada sulitnya mencapai tujuan lingkungan melalui pajak.

\section{Earmarked Taxes sebagai Suatu Contoh Prinsip Earmarking}

Earmarked Taxes adalah sebuah desain pendanaan yang mengacu kepada satu atau beberapa sumber dengan tujuan akhir yang spesifik. ${ }^{44}$ Earmarking adalah solusi yang menarik menurut politisi dan pembayar pajak, serta dianggap layak untuk pendanaan jaminan sosial, pendidikan, dan program lingkungan hidup. Earmarking menurut para pengambil kebijakan sebagai suatu alat untuk mengurangi resistensi tinggi pembayar pajak serta akuntabilitas yang jelas dari pembayar pajak mengenai peruntukan pajak tersebut. $^{45}$

Earmarking memiliki dua pengertian yang berkaitan dengan penganggaran (budgeting), yaitu sebagai pemasukan pendapatan secara umum yang nantinya dikonsentrasikan untuk proyek tertentu dan sebagai perpisahan aliran pendapatan program tertentu ke dalam anggaran lokal atau nasional. ${ }^{46}$

Dalam perkembangannya, earmarking tidak luput dari kritik. Marisiliani dan Renstrom memberikan kritik menggunakan contoh alokasi pajak kendaraan bermotor. ${ }^{47}$ Apakah pajak kendaraan bermotor seharusnya digunakan sepe-

(true opportunity cost) daripada sumber daya yang dicemar. Pungutan berupa pajak itu didesain untuk meningkatkan alokasi sumber daya dengan mempengaruhi perilaku ekonomi. Di sisi lain dengan diadakan pungutan teersebut dapat memberikan keuntungan bagi pendapatan. Sebaliknya, semua pajak lainnya selain pajak lingkungan pada dasarnya dirancang untuk meningkatkan pendapatan dan tidak dirancang dengan sengaja untuk dikonsentrasikan mengganggu keputusan ekonomi dan mendistorsi pilihan yang efisien. David Terkla, "The Efficiency Value of Effluent Tax Charges", Journal of Environmental Economics and Management, Vol. 11 (1984), hlm. 108. Lihat juga Oates, "Green Taxes: Can We Protect the Environment and Improve the Tax System at the Same time?", Southern Economic Journal, Vol. 61, No. 4 (April, 1995), hlm. 916-918.

${ }^{43}$ Mikael Skou Andersen, Governance by Green Taxes: Making Pollution Prevention Pay, (Manchester: St. Martin Press, 1994), hlm. 37.

${ }^{44}$ Ranjit S. Teja, "The Case of Earmarked Taxes", International Monetary Fund, Vol. 35 (September, 1988), hlm. 523. Dalam sejarahnya pengunaan kata earmark ditujukan kepada praktek penggembala yang membuat sobekan kepada telinga hewannya (notch) untuk menunjukan kepemilikan dari hewan ternak tersebut. Tim Weiner, "Sending Money to Home District: Earmarking and Congressional Pork Barrrel", New York Times, 13 Juli 1994, hlm. A01.

${ }^{45}$ Richard M Bird dan Joosung Jun, "Earmarking Theory and Korean Practice", International Tax Program Paper (2005), hlm. 15-17.

${ }^{46}$ Rob Porter dan Sam Walsh, "Earmarks in the Federal Budget Process", Harvard Law School Federal Budget Policy Seminar Briefing Paper, No. 16 (2008), hlm. 2.

${ }^{47}$ Laura Marsiliani dan Thomas I. RenstroEm, “Time Inconsistency in Environmental Policy: Tax Earmarking as a Commintment Solution”, The Economic Journal, Vol. 110 (Maret 2000), hlm. C 123. 
nuhnya untuk perkembangan jalan atau untuk transportasi umum? ${ }^{48}$ Sekalipun menurut mereka kedua argumen tersebut tidak rasional untuk menciptakan efisiensi ekonomi atau kesahjeteraan, akan tetapi memperlihatkan bahwa setiap golongan ingin mendapatkan bagian yang lebih besar dari 'public cake'. Argumen yang dibawa bagi masing-masing kelompok adalah bahwa bagian tersebut harus disesuaikan dengan apa yang mereka anggap dibutuhkan. ${ }^{49}{ }^{50}$ Sekalipun menimbulkan masalah, earmarking pajak lingkungan merupakan hal yang umum dilakukan di berbagai negara seperti di Eropa, ${ }^{51}$ Jepang, ${ }^{52}$ dan Amerika Serikat.
Secara khusus, pemberlakuan earmarking dalam hal lingkungan dapat dibenarkan karena sesuai dengan prinsip pencemar membayar. Hal ini juga disetujui oleh Pigou yang secara implisit menyatakan bahwa earmarking pajak lingkungan dapat dialokasikan untuk memperbaiki kerugian pada masyarakat oleh pencemar. ${ }^{53}$

Secara politik, earmarking dapat dibenarkan dengan melihat dua hal yaitu sebagai bentuk precommitment dan alat transparansi..$^{54}$ Deran menyatakan ada empat keuntungan yang didapat dari penggunaan earmarking baik secara ekonomi maupun non-ekonomi yaitu: ${ }^{55}$

\section{${ }^{48}$ Ibid. \\ ${ }^{49}$ Ibid.}

50 Ibid.

${ }^{51}$ Di Eropa terutama negara Perancis. Jerman, Italia, dan Belanda. Earmarking pajak lingkungan dikhususkan kepada pungutan pencemaran air (water pollution charges). Ibid.

${ }^{52}$ Di Jepang merujuk kepada pendapatan dari pajak emisi (emission taxes) yang digunakan untuk kompensasi kepada korban hasil pencemaran. Ibid.

${ }^{53}$ Claudia Alexandra Dias Soares, op.cit., hlm. 47.

54 Rebecca M. Kysar, Listening to Congress: Earmark Rules and Statutory Interpretation, Cornell Law Review. Volume 94, (2009), hlm. 526-534. Pada dasarnya fungsi dari adanya earmark sebagai precommitmen device adalah bahwa aturan-aturan legislatif (yang berasal dari earmark) didasari dari 'veil of ignorance' Rawlsian yang memaksa pembuat aturan untuk merumuskan aturan demi kepentiungan publik semata tanpa bisa mencampuradukan kepentingan lain didalamnya. Secara khusus, aturan tersebut nantinya akan diberlakukan tanpa melihat siapa yang akan diuntungkan atau dirugikan dari pemberlakuannya. Hal ini dalam bahasa Rawlsian dikenal dengan sebutan original position atau posisi sebenarnya. Lebih lanjut dengan pemberlakukan earmark pembuat kebijakan dapat mengantispasi diri dari kurangnya disiplin diri (dalam hal penganggaran). Dalam hal ini Elster menyatakan demikian 'person acts at one point in time in order to ensure that at some later time he will perform an act that he could but would not have performed without that prior act.' Dalam Jon Elster, Don't Burn Your Bridge Before You Come to It: Some Ambiguities and Complexities of Precommitment, Texas Law Review Volume. 81. (2003), hlm. 1754. Dalam penganggran sendiri precommitmen device ini timbul sebagai bentuk imbalan atas pengeluaran yang telah dilakukan. Lalu dari sisi earmarking sebagai alat transparasi. Hal ini dapat dibenarkan dengan melihat tujuannya untuk menghilangkan distrorsi yang terjadi akibat ketidaktahuan tentang isi atau tujuan alokasi yang tampaknya tidak sesuai dan juga ambigu.

${ }^{55}$ Elizabeth Deran, Earmarking and Expenditures: A Survey and a New Test, National Tax Journal, Volume. 18 No. 4 (Desember, 1965), hlm. 357. Bird juga mengungkapkan dalam beberapa kasus 
1. memberikan keuntungan dari penggunaan teori perpajakan;

2. memberikan kepastian pengeluaran yang efisien untuk tujuan pemerintahan yang diinginkan tanpa perlu memberikan tekanan kepada pembuatan kebijakan;

3. kestabilan yang lebih baik dan keberlanjutan pendanaan menimbulkan ongkos yang lebih rendah dalam proyek karena lebih cepat selesai;

4. tercipta link yang menghubungkan pajak dengan pengeluaran, sehingga peruntukan khusus dapat mengatasi pajak lain dan membantu menghasilkan sumber pendapatan baru.

Patterson menyatakan agar pajak lingkungan ini efektif dan efisien diperlukan adanya linkages dan earmarking revenue. ${ }^{56}$ Pajak lingkungan harus dide- katkan sedekat mungkin kepada pencemaran yang akan dikontrol. ${ }^{57}$ Apabila linkage-nya lemah, maka pajak gagal dalam memberikan dampak yang seharusnya diberikan kepada pencemaran dan menimbulkan distorsi yang tidak perlu ke dalam harga produksi dan keputusan konsumsi. ${ }^{58}$ Hal yang sama juga berlaku terhadap kebijakan revenue earmarking. Dalam menjalankan kebijakan tersebut. perlu juga dilakukan precommitment atau "tying the government's hands" dalam pengunaan pendapatan dari pajak lingkungan. ${ }^{59}$ Earmarking juga menunjukan bahwa pemerintah bertanggung jawab untuk berusaha memperbaiki lingkungan bukan hanya meningkatkan pajak..$^{60}$ Sebab tanpa earmarking mungkin saja bahwa pajak lingkungan tersebut digunakan untuk kepentingan lain. ${ }^{61} \mathrm{Hal}$

earmarking menjadi solusi atas penyelesaian pengganggaran dari sistem penganggaran umum yang bersifat birokratik dan berbelit-belit. Richard M. Bird, Budgeting and Expenditure Control in Columbia, Public Budgeting and Finance Volume. 2 No. 3 (1982), hlm. 91-95.

${ }^{56}$ Charles D. Patterson III, Environmental Taxes and Subsidies: What is the Appropriate Fiscal Policy for Dealing with Modern Environmental Problems? William. E Mary Environmental Law \& Policy Review Volume. 121. No. 121 (2000), hlm, 136. Linkages adalah bahasa yang digunakkan oleh Patterson untuk menunjukan alokasi khusus yang akan digunakan untuk pengeluaran.

${ }^{57}$ Stephen Smith, Environmental Tax Design, dalam Tim O'Riordan, ed. Ecotaxation (Park Square, Milton Park,Abingdon: Earthscan Routledge Publishing, 1997), hlm. 27. Berdasarkan pendapat European Environmental Agency ada enam untuk menciptakan kedekatan antara pajak dengan masalah lingkungan yang ada, 1) identifikasi dan menjelaskan permasalahn lingkungan yang ada, 2) rundingkan kebijakan yang dibutuhkan untuk mengintervensi and tuuan yang akan dicapai, 3) Merancang dan nilai dari efektifitas dari opsi-opsi kebijakan yang ada 4) merundingkan, memilih ninstrumen apa yang akan dipilih terhadap masalah lingkungan tersebut, 5) pengenalan terhadap instrument, implementasi kontrol, dan penegakan hukum, 6) modifikasi instrument setelah evaluasi yang dilakukan. European Environmental Agency, Environmental Taxes: Implementation and Environmental Effectiveness (Copenhagen: European Environmental Agency, 1996), hlm. 32.

${ }^{58}$ Daniel McCoy, Reflections on the Double Dividend Debate, dalam Tim O'Riordan, ed. Ecotaxation (Park Square, Milton Park, Abingdon: Earthscan Routledge Publishing, 1997), hlm. 207.

${ }^{59}$ Stephen Smith, op., cit., hlm. 29.

${ }^{60}$ Ibid., hlm. 30.

${ }^{61}$ Dalam beberapa kasus hal ini disebut dengan fiscal environmental taxes European Environmental Agency, op.cit, hlm. 21-22. 
tersebut berdampak terciptanya potensi policital backlash. ${ }^{62}$

\section{Teori Pendanaan Lingkungan Hidup: Suatu Tinjauan untuk Pemulihan Lingkungan}

Pendanaan Lingkungan Hidup adalah suatu sistem dan mekanisme pengelolaan dana yang digunakan bagi pembiayaan upaya perlindungan dan pengelolaan Lingkungan Hidup. ${ }^{63}$ Menurut Liu Jing, "dana” seringkali merujuk kepada instrumen keuangan yang terdiri dari kontribusi beberapa pelaku, pihak yang berpotensi menjadi korban, ataupun kelompok lain yang relevan. ${ }^{64}$ Akan tetapi, untuk memahami "dana" terkait pencemaran dan perusakan lingkungan, diperlukan pemahaman yang lebih terhadap struktur dan kategori pendanaan itu sendiri. ${ }^{65}$

Dana pencemaran dan perusakan dapat digunakan untuk melindungi pertanggungjawaban, intervensi ketika pertanggungjawaban tidak dapat di- mintakan, atau memberikan kompensasi kepada korban, terlepas apakah pihak yang bertanggung jawab sudah ditemukan atau belum. ${ }^{66}$

Kategori dari pendanaan itu sendiri berbeda-beda. Setiap ahli memiliki kategori pendanaannya masing-masing, misalnya saja kategori menurut Bocken dan Faure. Bocken mengelompokkan dana kompensasi ke dalam empat jenis, yaitu Guarantee Funds, Complementary Compensation Funds, Autonomous Compensation Funds, dan Funds Holding The Polluter Harmless. ${ }^{67}$ Agak berbeda dengan Bocken, Faure mengategorikan jenis dana menjadi empat, yaitu Guarantee Fund, Limitation Fund, Advancement Fund, dan General Compensation Fund. ${ }^{68}$ Sementara itu, terkait dengan sumber dananya, Liu Jing membaginya menjadi tiga tipe, yaitu dana yang bersumber dari pelaku pencemaran, dana yang bersumber dari pihak lain yang berkaitan ${ }^{69}$, dan dana yang bersumber dari masyarakat umum. ${ }^{70}$

${ }^{62}$ Charles D. Patterson III, op.cit, hlm. 137-140.

${ }^{63}$ Indonesia, op.cit., Pasal 1 angka 2.

${ }^{64}$ Liu Jing, Compensating Ecological Damage Comparative and Economic Observation (Cambridge: Intersentia, 2013), hlm. 143-144.

${ }^{65}$ Ibid., hlm. 143.

${ }^{66}$ Ibid., hlm. 143.

${ }^{67}$ H. Bocken, "Alternatives to Liability and Liability Insurance for The Compensation of Pollution Damages (part 2), Milieu aansprakelijkheid (Environmental Liability Law), 1988, hlm. 4-6.

${ }^{68}$ Michael G. Faure, "Alternative Compensation Mechanism as Remedies for Uninsurability of Liability", The Geneva Paper on Risk and Insurance, Vol. 29, No. 3, (July 2004), hlm. 480.

${ }^{69}$ Contoh dari pendanaan ini adalah IOCPF yang dibentuk oleh Fund Convention. Kontirbusi tahunan yang masuk ke dalam IOCPF berasal dari pihak yang menerima minyak lebih dari 150.000 ton daripada pemilik kapal yang mengangkut minyak, meskipun pemilik kapal ini lebih berpotensi menjadi pencemar. Liu Jing, op.cit., hlm. 145.

${ }^{70}$ Ibid., Liu Jing menjelaskan lebih lanjut bahwa dana yang bersumber dari masyarakat umum seringkali dikritik karena dianggap sebagai pemberian subsidi kepada industri-industri pencemar. 
Secara garis besar, pendapat Liu Jing juga sejalan dengan pendapat Bocken yang mengategorikan kondisi penggunaan dana dalam empat kategori. Pertama, penggunaan dana baru dapat dilakukan apabila korban tidak mendapatkan kompensasi dari sistem pertanggungjawaban dengan alasan pihak yang dimintai pertanggungjawaban tersebut pailit (tidak mampu membayar). Kedua, dilakukan jika tidak ada kompensasi yang bisa diperoleh dari sistem pertanggungjawaban yang ada. Ketiga, bisa dilakukan kapan saja, terlepas dari adanya kemungkinan bahwa korban bisa mendapat kompensasi di bawah sistem gugatan perdata. Keempat, dana digunakan untuk pertanggungjawaban atas sumber pencemaran yang tidak berbahaya ${ }^{71}$.

Merujuk pendapat di atas, Penulis menyimpulkan bahwa ada dana yang berfungsi sebagai lapisan ${ }^{72}$ namun ada juga dana yang berdiri sendiri. Dana yang berfungsi sebagai lapisan adalah dana tersebut baru dapat digunakan jika sistem pertanggungjawaban gagal memberikan kompensasi kepada pihak yang dirugikan, sedangkan dana yang berdiri sendiri adalah dana yang terlepas dari sistem pertanggungjawaban, sehingga bisa bersifat sebagai alternatif ataupun komplementer dari sistem pertanggungjawaban.

\section{Sistem Pengelolaan Pendanaan Amerika Serikat: Old Super- fund vs. New Superfund}

Salah satu mekanisme pendanaan lingkungan Amerika Serikat yang terkenal adalah Superfund Trust Fund (biasa disebut Superfund) yang dibentuk melalui CERCLA. Menurut Franklin, Superfund merupakan dana yang dibentuk sebagai sumber dana bagi EPA untuk melakukan pemulihan pemulihan terhadap lingkungan yang tercemar. ${ }^{73}$ Pengertian yang sama juga diberikan oleh Judy dan Probst yang menyatakan bahwa Superfund adalah salah satu mekanisme pendanaan untuk pemulihan serta penanggulangan lingkungan hidup yang rusak

${ }^{71}$ H. Bocken, op.cit., hlm. 10.

${ }^{72}$ Dalam Green Paper, diatur bahwa ada dua lapis kompensasi, yaitu pertanggungjawaban perdata yang disertai dengan asuransi tanggung jawab dalam lapis pertama dan dana kompensasi pada lapis kedua. (Commision of European Communities, "Communication from the Commision to the Cpuncil and Parliament and the Economic and Social Committee: Green Paper on remedying Environmental Damage", COM (93) 7 Final, May 14, 1993) Tetapi, Wibisana dalam tulisannya "The Myths of Environmental Compensation in Indonesia: Lesson from Sidoarjo Mudflow" menambahkan lagi lapisan kompensasi ini menjadi tiga lapisan, yaitu pertanggungjawaban dan asuransi tanggung jawab di lapis pertama, alternatif atas asuransi tanggung jawab di lapisan kedua dan dana kompensasi di lapisan ketiga. (A. G. Wibisana, "The Myths of Environmental Compensation In Indonesia: Lessons from Sidoarjo Mudflow", Progress Report for the 2008-2010 KNAW-SPIN Post Doctoral Research.)

${ }_{73}$ Nicole Franklin, "The Superfund Program Past and Present Funding Implications", (Tesis Virginia Commonwealth University, 2011), hlm. 8. 
atau tercemar yang ada dalam CERCLA. ${ }^{74}$

Pada dasarnya Superfund dibentuk untuk membiayai tindakan pemulihan terhadap wilayah yang tercemar namun Potentially Responsible Party (PRPs) tidak dapat ditemukan atau tidak mampu membayar. ${ }^{75}$ Selain untuk membiayai kedua hal tersebut, Superfund juga digunakan untuk melakukan pemulihan terlebih dahulu sebelum mencari PRPs yang bertanggung jawab dan mendapatkan penggantian uang atas pemulihan yang telah dilakukan. Hal ini bisa dilihat dari adanya mekanisme paksaan ${ }^{76}$ bagi PRPs ketika harus bertanggung jawab atas wilayah yang tercemar berupa Cost $R e$ covery. ${ }^{77}$ Environmental Protection Agency (EPA) akan melakukan pemulihan terlebih dahulu dengan menggunakan dana yang ada dalam Superfund dan kemudian akan meminta PRPs untuk mengganti uang yang telah digunakan tersebut ${ }^{78}$

Hal yang perlu ditinjau lebih jauh dari mekanisme pendanaan ini adalah sumber dana Superfund serta pengalokasiannya. Sejak tahun 1980 hingga 1995 (disebut sebagai Old Superfund), sumber dana utamanya adalah pajak khusus berupa cukai untuk bahan kimia dan minyak serta pajak lingkungan bagi perusahaan. ${ }^{79}$ Sistem yang digunakan adalah

${ }^{74}$ Martha L. Judy dan Katherine N. Probst, “Superfund at 30”, Vermont Journal of Environmental Law, Vol. 11, hlm. 213.

${ }^{75}$ David M. Bearden, "Comprehensive Environmental Response, Compensation, and Liability Act: A Summary of Superfund Cleanup Authorities and Related Provisions of the Act", Congressional Research Service, (Juni 2012), hlm. 3. Terhadap kondisi dimana PRPs tidak mampu membayar, penulis menyarankan bahwa dana yang dibentuk ini sifatnya bukan berdiri sendiri, namun sebagai lapisan, untuk mencegah timbulnya moral hazard. Moral hazard adalah salah satu fenomena yang dikenal dalam asuransi dimana sikap perilaku seseorang (dalam asuransi disebut tertanggung) akan berubah segera setelah risiko dihilangkan darinya. (Michael G. Faure dan David Grimeaud, "Financial Assurance Issues of Environmental Liability", Final Report, (Maastricht University and European Centre For Tort and Insurance Law, 2000), hlm 120). Pengertian Moral Hazard juga disampaikan serupa oleh S. Shavell yang menyatakan: "Moral hazard refers here to the tendency of insurance protection to alter an individual's motive to prevent loss" (Steven Shavell, "On Moral Hazard and Insurance", Quarterly Journal of Economics, Vol. 93, No. 4 (November 1979), hlm. 541) Jadi, moral hazard dapat timbul apabila seseorang merasa tanggung jawab bisa dipindahkan kepada pihak lain, sehingga ia bisa berbuat apapun tanpa menimbulkan risiko yang merugikan dirinya. Dalam hal pendanaan lingkungan, dana lingkungan perlu berfungsi sebagai lapisan untuk menghindari perilaku ini, sehingga PRPs tetap memiliki tanggung jawab atas pencemaran yang dilakukan, baik dalam bentuk pertanggungjawaban perdata maupun asuransi yang preminya dibayarkan setiap bulan oleh pencemar. (Pembahasan tentang lapisan telah dijelaskan dalam sub bab Pendanaan Lingkungan Hidup).

${ }^{76}$ Ada tiga pilihan paksaan bagi PRPs ketika harus bertanggung jawab ketika wilayah tercemar, yaitu voluntary settlement agreement, cost recovery, atau Judicial/Administrative Order. (United States Environmental Agency, "Superfund Enforcement: 35 Years of Protecting Communities and the Environment", https:/ / www.epa.gov/enforcement/superfund- enforcement-35-years-protecting-communities-andenvironment, diakses pada tanggal 16 Januari 2018.

77 Bearden, op.cit., hlm. 1

${ }^{78}$ United States Environmental Agency, op.cit.

${ }^{79}$ Bearden, op.cit., hlm. 20. 
dengan mengambil sejumlah biaya dari pencemar (dalam hal ini, yang memproduksi atau mengeluarkan limbah bahan kimia dan minyak bumi) yang dimasukan ke dalam Superfund untuk membiayai kegiatan pembersihan (clean up) dari produksi dan pembuangan bahan kimia dan minyak bumi. ${ }^{80}$ Dalam versi Old Superfund, pengaturan dan mekanisme pendanaannya telah sesuai dengan prinsip pencemar membayar dan konsep earmarking.

Sayangnya, kewenangan memungut pajak khusus untuk dana Superfund berakhir tahun 1995. ${ }^{81}$ Meskipun telah berakhir, dana Superfund masih tersedia hingga akhir tahun 2003. ${ }^{82}$ Sejak berakhirnya kewenangan memungut pajak lingkungan pada tahun 1995 (disebut sebagai New Superfund), setiap tahunnya, pemerintahan Clinton meminta Kongres untuk mengembalikan kewenangan pemungutan pajak ini, namun Kongres tidak menerimanya. ${ }^{83}$

Saat pemerintahan Bush, Bush membatalkan seluruh permintaan otorisasi pemungutan pajak yang diajukan sebe- lumnya oleh pemerintahan Clinton. Hal ini tentu berakibat pada berubahnya sumber dana utama yang awalnya berasal dari pajak khusus lingkungan menjadi berasal dari pajak umum. ${ }^{84}$ Bahkan, masyarakat yang membayar pajak pada akhirnya menanggung beban biaya untuk pemulihan lingkungan yang lebih besar daripada perusahaan. Hal tersebut bisa dilihat dari data tahun 1991-1995, porsi kontribusi pajak umum terhadap Superfund hanya $17 \%$, namun di tahun 2000-2002 menjadi 50\%. ${ }^{85}$

Penolakan serta pembatalan terjadi karena beberapa faktor politik. Penolakan dilakukan oleh Kongres yang ada dalam kendali The Republican, yang telah lama menyatakan bahwa program Superfund hanya membuang uang untuk membuktikan pihak yang bertanggung jawab pada suatu wilayah tercemar. ${ }^{86}$ Sebagai informasi, The Republican merupakan pihak yang memang melakukan penolakan terhadap pajak. Hal ini bisa dilihat dari pidato Bush yang terkenal, yaitu "Read my lips: No new taxes" ${ }^{87}$ Bush juga menunjukkan ketidakberpihakan-

${ }^{80}$ Craig Brett dan Michael Keen, "Political Uncertainty and The Earmarking of Environmental Taxes", Journal of Public Economics, Vol. 75 (2000), hlm. 316.

${ }^{81}$ Nicole Franklin, op.cit., hlm. 8

${ }^{82}$ Ibid.

${ }^{83}$ Charles W. Schmidt, "Not-So-Superfund: Growing Needs vs. Declining Dollars", The Environmental Health Perspectives", Vol. 111, No. 3 (Maret, 2003), hlm. 164.

${ }^{84}$ Ibid.

${ }^{85}$ Mark Haggerty dan Stephanie A. Welcomer, "The Ascendance of Enabling Myths", Journal of Economic Issues, Vol. 37, No. 2, hlm. 453-454.

${ }^{86}$ Major Garrett, "White House Won't Tax Corporations For Superfund Cleanup", http:/ / edition. cnn.com/2002/ALLPOLITICS/02/24/bush.superfund/, diakses pada 20 Januari 2019.

${ }^{87}$ Lily Rothman, The Story Behind Geogre H.W. Bush's Famous ‘Read My Lips: No New Taxes' Promise", http:/ / time.com/3649511/george-hw-bush-quote-read-my-lips/, diakses pada 20 Januari 2019. 
nya pada pajak dengan melakukan pemotongan pajak untuk keluarga dan investor pada masa pemerintahannya. ${ }^{88}$

Pembatalan yang dilakukan oleh Bush juga mungkin disebabkan keluhan perusahaan minyak dan bahan kimia serta perusahaan lainnya tentang pajak, yang merasa sangat terbebani dengan pajak yang berjumlah sekitar $\$ 4$ juta/ hari. ${ }^{89}$

Meskipun mendapat banyak penolakan, pada dasarnya pajak ini sangat dibutuhkan. Hal ini mengingat bahwa filosofi fundamental dari Superfund adalah polluter pays principle dan dengan dihapuskannya pajak ini, terjadi penyimpangan terhadap prinsip pencemar membayar itu sendiri, terjadi penurunan jumlah dana dan penurunan jumlah wilayah tercemar yang berhasil dipulihkan.

Sejak masa pemerintahan Bush, tindakan pemulihan wilayah tercemar mulai melambat. Tahun 2001, EPA menyelesaikan pemulihan di 47 wilayah. Tahun 2002, 65 wilayah yang kemudian berkurang menjadi 4 dan juga berlanjut terjadi di tahun 2003.90 Jumlah pembersihan yang dilakukan pada saat itu hanya setengah dari jumlah wilayah yang dibersihkan pada akhir tahun 1990.91
Selain itu, terjadi juga penyimpangan earmarking dalam versi New Superfund. Hal ini dikarenakan pajak umum yang seharusnya digunakan untuk kepentingan masyarakat secara luas, justru dialokasikan untuk pencemaran lingkungan, sehingga seolah-olah menunjukkan penggunaan pajak umum untuk memberikan subsidi bagi pencemar.

Melihat sistem pendanaan pemulihan yang ada di Amerika Serikat melalui Superfund, dapat dilihat bahwa politik membawa dampak yang cukup besar terhadap pengambilan kebijakan. Bahkan, Haggerty dan Welcomer menyatakan bahwa dalam pemerintahan Bush, prinsip pencemar membayar sudah tidak bisa lagi berfungsi sebagai prinsip/ asas dasar, namun sebagai mitos. Melalui kebijakan yang diputuskan oleh pemerintahan Bush, pihak yang diuntungkan adalah industri/perusahaan, sedangkan masyarakat secara umum. semakin dibebani oleh tanggungan atas pencemaran yang tidak mereka lakukan.

Haggerty dan Welcomer juga mengutip salah satu ucapan pengacara senior untuk Environmental Defense Fund yang menyatakan bahwa sebagai prinsip, pajak harus dibayar oleh kelom-

\footnotetext{
${ }^{88}$ Kimberly Amadeo, "Bush Tax Cuts, Causes, Expiration, and Their Impact to Economy", https:/ / www.thebalance.com/president-george-bush-tax-cuts-3306331, diakses pada pada 22 Januari 2019.

${ }^{89}$ Katherine Q. Seelye, "Bush Proposing Policy Changes On Toxic Sites", https://www.nytimes. com/2002/02/24/us/bush-proposing-policy-changes-on-toxic-sites.html, diakses pada 21 Januari 2019.

${ }^{90}$ Mark Haggerty dan Stephanie A. Welcomer, op.cit., hlm. 454-456.

${ }^{91}$ Ibid.
} 
pok yang memiliki keterkaitan dengan permasalahan yang ada. Kelompok ini adalah industri/perusahaan, bukan individu yang tidak memiliki keterkaitan apapun, yaitu masyarakat umum. ${ }^{92}$ Pengacara tersebut menyatakan bahwa ini mungkin dikatakan sebagai 'rough justice', namun 'rough justice' lebih baik daripada tidak sama sekali. ${ }^{93}$

Apakah Indonesia juga akan menerapkan hal serupa dengan Amerika Serikat dengan menggunakan APBN/ APBD sebagai sumber dana untuk pemulihan lingkungan? Apakah pemerintah di tahun politiknya ini tidak cukup berani menerapkan pajak khusus untuk lingkungan dan menghapuskan APBN/ APBD sebagai sumber bagi pendanaan lingkungan serta melakukan earmarking pajak?

\section{Peraturan Pendanaan Lingkung- an Hidup di Indonesia dan Po- tensinya terhadap Penyimpang- an Prinsip Pencemar Membayar dan Earmarking}

Pada dasarnya, Pasal 42 dan Pasal 43 UU PPLH jo PP 46/2017, serta Perpres 77/2018 merupakan langkah yang baik untuk memberikan perlindungan, mem- perbaiki, ataupun mencegah terjadi pencemaran/kerusakan pada lingkungan hidup. Namun, ada beberapa hal yang perlu dikritisi terutama pada PP 46/2017 maupun Perpres 77/2018.

Pertama, mengenai sumber dana bagi dana penanggulangan pencemaran dan/atau kerusakan dan pemulihan lingkungan hidup serta alokasi pendanaan tersebut. Dalam kedua peraturan tersebut, disebutkan bahwa dana penanggulangan pencemaran dan/atau kerusakan dan pemulihan lingkungan hidup dapat bersumber dari APBN serta APBD. ${ }^{94}$ Hal ini berarti seluruh masyarakat, baik yang memiliki keterkaitan dengan pencemaran yang ada atau tidak, akan ikut menanggung beban biaya pemulihan lingkungan.

Penyaluran dana lingkungan hidup dapat dilakukan dengan mekanisme:

a. perdagangan karbon;

b. pinjaman;

c. subsidi;

d. hibah; dan/atau

e. mekanisme lainnya sesuai dengan ketentuan peraturan perundang-undangan. ${ }^{95}$

Ketentuan tersebut menunjukkan terjadi penggabungan penyaluran dana. Kedua sumber dana yang berbe-

\footnotetext{
92 Ibid., hlm. 454.

93 Ibid.

${ }^{94}$ Indonesia, Peraturan Pemerintah Republik Indonesia tentang Instrumen Ekonomi Lingkungan Hidup, PP No. 46 Tahun 2017, LN No. 228 Tahun 2017, TLN No. 6134, Pasal 27 ayat 1 juncto Indonesia, Peraturan Presiden tentang Pengelolaan Dana Lingkungan Hidup, PerPres No. 77 Tahun 2018, LN No. 160 Tahun 2018, Pasal 4 ayat 1.

95 Ibid., Pasal 6 ayat 2.
} 
da dicampuradukkan untuk peruntukan yang sama tanpa dijelaskan penggunaan spesifik masing-masing dana. Hal ini menyimpangi prinsip kompensasi ${ }^{96}$, juga berarti telah menyimpangi juga prinsip pencemar membayar serta menunjukkan adanya penyimpangan alokasi pendanaan.

\section{Faure dan Hartlief berpendapat} bahwa ada dua prinsip utama kompensasi, yaitu kewajiban untuk memberikan kompensasi hanya ada pihak yang berkontribusi atas terjadinya risiko dan yang kedua adalah kewajiban untuk berkontribusi atas kompensasi harus setara dengan kontribusi terhadap risiko yang ada. ${ }^{97}$ Kedua prinsip ini sejalan dengan polluter pays principle dan seyogyanya dijalankan oleh pemerintah dalam kebijakan lingkungan hidup.

Sebenarnya, $\mathrm{APBN}^{98}$ atau $\mathrm{APBD}^{99}$ dapat dijadikan salah satu sumber pendanaan lingkungan, dengan syarat harus dilakukan pungutan secara khusus dan dilakukan earmarking atas hasil pungutan tersebut. Pungutan bisa dalam bentuk $\mathrm{PNBP}^{100}$ berupa pajak lingkungan. ${ }^{101}$ Namun, belum ada satu pun peraturan di Indonesia yang mengatur lebih detail terkait pajak lingkungan terutama terkait dengan alokasi penerimaan ataupun earmark yang seharusnya dilakukan.

${ }^{96}$ Faure dan Hartlief berpendapat bahwa ada dua prinsip utama kompensasi, yaitu kewajiban untuk memberikan kompensasi hanya ada pihak yang berkontribusi atas terjadinya risiko dan yang kedua adalah kewajiban untuk berkontribusi atas kompensasi harus setara dengan kontribusi terhadap risiko yang ada. Michael G. Faure dan Tom Hartlief, "Compensation Funds versus Liability and Insurance for Remedying Environmental Damage", Review of European Community and International Environmental Law (RECIEL), Vol. 5, Issue 4 (1996), hal. 323.

${ }^{97}$ Michael G. Faure dan Tom Hartlief, "Compensation Funds versus Liability and Insurance for Remedying Environmental Damage", Review of European Community and International Environmental Law (RECIEL), Vol. 5, Issue 4 (1996), hlm. 323.

${ }^{98}$ Indonesia, Undang-Undang tentang Keuangan Negara, UU No. 17 tahun 2003, LN No. 43 tahun 2003, TLN No. 4286, Pasal 1 angka 13 menyatakan Pendapatan negara adalah hak pemerintah pusat yang diakui sebagai penambah nilai kekayaan bersih. Sedangkan berdasarkan Pasal 1 angka 2 UU APBN menyatakan 'Pendapatan Negara adalah hak Pemerintah Pusat yang diakui sebagai penambah kekayaan bersih yang terdiri atas Penerimaan Perpajakan, Penerimaan Negara Bukan Pajak, dan Penerimaan Hibah.' (garis bawah dari penulis). Dengan demikian PNBP merupakan salah satu komponen pendapatan negara di dalam APBN. Indonesia, Undang-Undang tentang Anggaran Pendaptan dan Belanja Negara tahun Anggaran 2019, UU No. 12 tahun 2018, LN No. 223 tahun 2003, TLN No. 6263, Pasal 1 angka 2.

${ }^{99}$ Konsep yang sama berlaku juga terhadap pendapat daerah yang masuk ke dalam APBD. Lihat dalam Indonesia, Undang-Undang tentang Pemerintahan Daerah, UU No. 32 tahun 2004, LN No. 125 tahun 2004, TLN No. 4437 Pasal 157.

${ }^{100}$ Indonesia, Undang-Undang tentang Penerimaan Negara Bukan Pajak, UU No. 9 Tahun 2018, LN No. 147 Tahun 2018, TLN 6245. Pasal 1 angka 1 menyatakan:

"Penerimaan Negara Bukan Pajak yang selanjutnya disingkat PNBP adalah pungutan yang dibayar oleh orang pribadi atau badan dengan memperoleh manfaat langsung maupun tidak langsung atas layanan atau pemanfaatan sumber daya dan hak yang diperoleh negara, berdasarkan peraturan perundang-undangan, yang menjadi penerimaan Pemerintah Pusat di luar penerimaan perpajakan dan hibah dan dikelola dalam mekanisme anggaran pendapatan dan belanja negara."

101 Penjelasan Pasal 43 ayat (3) huruf b UU PPLH. 


\section{Penutup}

Pembuatan suatu peraturan perlu memperhatikan prinsip dasar. Sangat disayangkan ketika ada suatu peraturan yang dibentuk untuk perlindungan dan pengelolaan lingkungan hidup, namun justru mengesampingkan prinsip hukum lingkungan, dalam hal ini prinsip pencemar membayar dan earmarking.

PP 46/2017 dan Perpres 77 /2018 telah menyimpangi prinsip pencemar membayar dan earmarking. Melalui peraturan ini, APBN dan APBD dijadikan salah satu sumber pendanaan lingkungan dan dilakukan penggabungan penggunaan dana dari dua jenis berbeda yang mana seharusnya tiap jenis memiliki tujuan penggunaannya masing-masing. Pemerintah perlu mengambil langkah konkret untuk memperbaiki peraturan tersebut.

Pelaksanaan pendanaan lingkungan hidup yang ada dalam Old Superfund dapat menjadi contoh bagi Indonesia untuk melakukan perbaikan. Apabila pemerintah tidak mengambil langkah perbaikan, maka prinsip pencemar membayar dan earmarking dalam pengelolaan dana lingkungan hidup hanya akan menjadi mitos. 


\section{DAFTAR PUSTAKA}

\section{Peraturan Perundang-Undangan}

Amerika Serikat, Comprehensive Environmental Response, Compensation, and $\mathrm{Li}$ ability Act ('CERCLA')

Indonesia. Undang-Undang tentang Perubahan atas Undang-Undang Nomor 11 Tahun 1995 tentang Cukai. UU No. 39 Tahun 2007. LN No. 105 Tahun 2007. TLN No. 4755.

. Undang-Undang tentang Pajak Daerah dan Retribusi Daerah. UU No. 28 Tahun 2009. LN No. 130 Tahun 2009. TLN No. 5049.

- Undang-Undang tentang Perlindungan dan Pengelolaan Lingkungan Hidup. UU No. 32 Tahun 2009. LN No. 140 Tahun 2009. TLN No. 5059. - Undang-Undang tentang Penerimaan Negara Bukan Pajak. UU No. 9 Tahun 2018. LN No. 147 Tahun 2018. TLN 6245.

Peraturan Pemerintah Republik Indonesia tentang Instrumen Ekonomi Lingkungan Hidup. PP No. 46 Tahun 2017. LN No. 228 Tahun 2017. TLN No. 613.

. Peraturan Presiden Tentang Rencana Pembangunan Jangka Menengah Nasional Tahun 2015-2019. Perpres No. 2 Tahun 2015. LN No. 3 Tahun 2015.

Peraturan Presiden tentang Pengelolaan Dana Lingkungan Hidup, Perpres No. 77 Tahun 2018. LN No. 160 Tahun 2018.

\section{Buku}

Adler, John dan David Wilkinson. Environmental Law and Ethics. London: Macmillan Press. 1999.

Anderson, Mikael Skou Andersen. Governance by Green Taxes: Making Pollution Prevention Pay. Manchester: St. Martin Press. 1994.

Baumol, William dan Wallace Oats. The Theory of Environmental Policy: ed. 2. cet. 8. Cambridge: Cambridge University Press, 1988.

Beder, Sharon. "The Polluter Pays Principle." Dalam Sharon Beder, Environmental Principles and Policies. An Interdisciplinary Introduction. London: Earthscan. 2006.

Boyle, Alan dan Patricia Birnie. International Law and the Environment. $2^{\text {nd }}$ Edition. Oxford: Oxford University Press. 2002.

Cooter, Robert dan Thomas Ulen. Law and Economics. $6^{\text {th }}$ edition. New York: Addison-Wesley. 2012.

Faure, Michael G., Marjaan Peeters, dan Andri G. Wibisana. "Economic Instruments: Suiteed Developing Countries?" Dalam Michael Faure dan Nicole Niessen, Environmental Law in Development: Lesson from the Indonesian Experience. Northampton, Edward Elgar. 2010.

H. Smets, 'The Polluter Pays Principle in the Early 1990s'. Dalam L. Campiglio, L. Pineschi, D. Siniscalco dan T. Treves (eds). The Environment After Rio: 
International Law and Economics. London: Graham and Trotman. 1994.

Keraf, A. Sonny. Etika Lingkungan Hidup. Jakarta: Kompas. 2010.

Liu, Jing. Compensating Ecological Damage Comparative and Economic Observation. Cambridge: Intersentia. 2013.

Mansfield, E. Principles of Microeconomics. New York: W.W. Norton \& Company. 1983.

McCoy, Daniel. "Reflections on the Double Dividend Debate" dalam Ecotaxation diedit oleh Tim O'Riordan, Park Square, Milton Park, Abingdon: Earthscan Routledge Publishing, 1997.

Pigou, Arthur Cecil. The Economics of Welfare. London: Macmillian and Co. Limited. 2002.

Pindyck, Robert S. dan Daniel L. Rubinfeld. Microeconomics. New Jersey: Prentice Hall. 2001.

Sands, Philippe. Principles of International Environmental Law $2^{\text {nd }}$ Edition. Cambridge: Cambridge University Press. 2003.

Sands, Philippe dan Paolo Galizi. Documents in International Environmental Law. Cambridge: Cambridge University Press. 2004.

Smith, Stephen. "Environmental Tax Design" dalam Ecotaxation diedit oleh Tim O'Riordan, Park Square, Milton Park. Abingdon: Earthscan Routledge Publishing, 1997.
Syarif, Laode $\mathrm{M}$ dan Andri Wibisana. Hukum Lingkungan, Teori, Legislasi, dan Studi Kasus. Jakarta: INCLE. 2010.

Taylor, Paul W. Respect for Nature: A Theory of Environmental Ethics. Princeton: Princeton University Press. 1986.

Wilkinson, David. Law and Evironment. London: Roudledge Publishing. 2002.

\section{Artikel Jurnal dan Media Massa}

Bird, Richard M dan Joosung Jun. "Earmarking Theory and Korean Practice." International Tax Program Paper. 2005.

Bird, Richard M. "Budgeting and Expenditure Control in Columbia." Public Budgeting and Finance Volume. 2 No. 3. 1982.

Bocken, H. “Alternatives to Liability and Liability Insurance for The Compensation of Pollution Damages (part 2). Milieu aansprakelijkheid (Environmental Liability Law). 1988.

Brett, Craig dan Michael Keen. "Political Uncertainty and The Earmarking of Environmental Taxes". Journal of Public Economics. Vol. 75. 2000.

Cordato, Roy E. “The Polluter Pays Principle: A Proper Guide for Environmental Policy." Institute for Research on the Economics of Taxation (IRET) Studies in Social Cost, Regulation and the Environment. No. 6. 2001.

D' Agre, R. C. dan E. K. “Hunt, Environmental Pollution, Externalities, and 
Conventional Economic Wisdom: A Critique". B.C. Environmental Affair Law Review. Vol. 1. 1971.

Deran, Elizabeth. "Earmarking and Expenditures: A Survey and a New Test." National Tax Journal, Volume. 18 No. 4. 1965.

Draper, John William. “Why Law Now Needs to Control Rather than Follow Neo-Classical Economics". Pace Environmental. Law Review. Vol. 33. 2016.

Elster, Jon. “Don't Burn Your Bridge Before You Come to It: Some Ambiguities and Complexities of Precommitment." Texas Law Review Volume. 81. 2003,

Faure, Michael G. "Alternative Compensation Mechanism as Remedies for Uninsurability of Liability." The Geneva Paper on Risk and Insurance. Vol. 29. No. 3. July 2004.

Faure, Michael G dan Tom Hartlief. "Compensation Funds versus Liability and Insurance for Remedying Environmental Damage". Review of European Community and International Environmental Law (RECIEL). Vol. 5. Issue 4. 1996.

Haggety, Mark dan Stephanie A. Welcomer. "The Ascendance of Enabling Myths". Journal of Economic Issues. Vol. 37. No. 2.

Judy, Martha L. dan Katherine N. Probst. "Superfund at 30". Vermont Journal of Environmental Law. Vol. 11.
Marsiliani, Laura dan Thomas I. RenstroÈm. "Time Inconsistency in Environmental Policy: Tax Earmarking as a Commintment Solution". The Economic Journal. Vol. 110. Maret 2000.

Meyer, Jan-Henrik. “Who Should Pay for Pollution? The OECD, the European Communities and the Emergence of Environmental Policy in the Early 1970s". European Review of History: Revue européenne d'histoire. 24:3. 2017.

Mixon, John. "Neoclassical Economics and the Erosion of Middle-Class Values: An Explanation for Economic Collapse." Notre Dame Journal Law Ethics \& Public Policy. Vol. 24. 2010.

Oates. "Green Taxes: Can We Protect the Environment and Improve the Tax System at the Same time?" Southern Economic Journal. Vol. 61. No. 4 April, 1995.

Patterson III, Charles. "Environmental Taxes and Subsidies: What is the Appropriate Fiscal Policy for Dealing with Modern Environmental Problems?" William. \& Mary Environmental Law \& Policy Review Volume. 121. 2000.

Pearson, Charles S. "Testing the System: GATT + PPP $=$ ?" Cornell International Law Journal. Vol. 27. Issue 3. Article 4. 1994.

Porter, Rob dan Sam Walsh. "Earmarks in the Federal Budget Process." Harvard Law School Federal Budget Policy Seminar Briefing Paper. No. 16. 
Rebecca, Kysar M. “Listening to Congress: Earmark Rules and Statutory Interpretation." Cornell Law Review. Volume 94. 2009.

Sandmo, Agnar. "Direct Versus Indirect Pigouvian Taxation." European Economic Review. Vol. 7. 1976.

Schmidt, Charles W. “Not-So-Superfund: Growing Needs vs. Declining Dollars." The Environmental Health Perspectives. Vol. 111. No. 3. Maret, 2003.

Shavell, S. "On Moral Hazard and Insurance." Quarterly Journal of Economics. Vol. 93. No. 4. November 1979.

Sunstein, Cass R. “Irreversible and Catastrophic: Global Warming, Terrorism, and Other Problems: Eleventh Annual Lloyd K. Garrison Lecture on Environmental Law". Pace Environmental Law Review. Vol. 23. Januari 2006.

Teja, Ranjit S. “The Case of Earmarked Taxes." International Monetary Fund. Vol. 35. September. 1988.

Terkla, David. "The Efficiency Value of Effluent Tax Charges." Journal of Environmental Economics and Management. Vol. 11. 1984.

Weiner, Tim. "Sending Money to Home District: Earmarking and Congressional Pork Barrrel." New York Times. 13 Juli 1994.

Weiss, Edith Brown. "Our Rights and Obligations to Future Generations for the Environment." The American Journal of International Law. Vol. 84. 1990.

\section{Lain-lain}

Amadeo, Kimberly. Bush Tax Cuts, Causes, Expiration, and Their Impact to Economy. https://www.thebalance. $\mathrm{com} /$ president-george-bush-taxcuts-3306331. Diakses pada 22 Januari 2019.

Bearden, David M. “Comprehensive Environmental Response, Compensation, and Liability Act: A Summary of Superfund Cleanup Authorities and Related Provisions of the Act". Congressional Research Service. Juni 2012.

European Environmental Agency. Environmental Taxes: Implementation and Environmental Effectiveness. Copenhagen: European Environmental Agency, 1996.

Faure, Michael. G dan David Grimeaud. "Financial Assurance Issues of Environmental Liability." Final Report. Maastricht University and European Centre For Tort and Insurance Law. 2000.

Franklin, Nicole. "The Superfund Program Past and Present Funding Implications". Tesis Virginia Commonwealth University. 2011.

Garrett, Major. White House Won't Tax Corporations For Superfund Cleanup. http://edition.cnn.com/2002/ ALLPOLITICS/02/24/bush.superfund/. Diakses pada 20 Januari 2019.

Joint Working Party on Trade and Environment. The Polluter-Pays Principle as It Relates to International Trade. Paris: OECD. 2002. 
K. Arrow. "The Organization of Economic Activity: Issues Pertinent to the Choice of Market Versus Nonmarket Allocation". (Disampaikan pada The Analysis and Evaluation of Public Expenditures: The PPB System). Washington D.C.: Joint Economic Committee, 91st Congress, 47-64, 1969.

OECD. The Polluter-Pays Principle: OECD Analyses and Recommendations. Paris, OECD. 1992.

Rothman, Lily. The Story Behind Geogre H.W. Bush's Famous ‘Read My Lips: No New Taxes' Promise. http:// time.com/3649511/george-hwbush-quote-read-my-lips/. Diakses pada 20 Januari 2019.

Seelye, Katherine Q. Bush Proposing Policy Changes On Toxic Sites. https:// www.nytimes.com/2002/02/24/ us/bush-proposing-policy-changeson-toxic-sites.html. Diakses pada 21 Januari 2019.

Soares, Alexandra Dias. "The Design Features of Environmental Tax". Doctoral Thesis London School of Economics. September 2011.

United States Environmental Agency. Superfund Enforcement: 35 Years of Protecting Communities and the Environment. www.epa.gov/enforcement/ superfund- enforcement-35-yearsprotecting-communities-andenvironment. Diakses pada 16 Januari 2018.

Wibisana, Andri Gunawan. Prinsip-Prinsip Hukum Lingkungan, Bahan Ajar
Fakultas Hukum Universitas Indonesia. Minggu II. Draft Oktober 2014.

"The Myths of Environmental Compensation In Indonesia: Lessons from Sidoarjo Mudflow." Progress Report for the 2008-2010 KNAWSPIN Post Doctoral Research. 